\title{
The Elephant in the Room of WTO Reform: China*
}

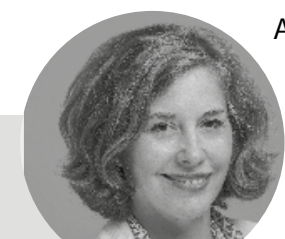

is Senior Research Fellow at Bruegel, Brussels and non resident Research Fellow at Real Instituto Elcano, Madrid. She also serves as adjunct professor at Hong Kong University of Science and Technology.

\section{Alicia García-Herrero}

As the World Trade Organization finally changes its leadership after a long impasse to install a female candidate from the emerging world, Ms. Okonjo-Iweala, it seems like a good time to review the experience of one of the WTO's most transformative moments, namely the accession of the most populous country in the world, China. China was not only the paradigm of an emerging economy trying to participate in the global economy, but was still an economy governed by central planning and socialist principles. It is important to note, however, that China started its accession process before the collapse of the Soviet Union, so it is much more driven by its own reform zeal than as a way out of a failing economic model. In fact, a number of countries that were either part of the Soviet Union or in its sphere went through WTO accession before China. More specifically, five former members of the Soviet Union, namely Kyrgyz, Latvia, Estonia, Georgia and Lithuania, together with others in Soviet Union's sphere, such as Albania and Bulgaria, succeeded in becoming WTO members by end of November 2000.

China's accession, though, was very different from that of those countries as it started well before and was much lengthier and tumultuous. Interestingly, however, China also experienced a much faster transformation than any of these countries, at least when measured in terms of economic growth. This article will explore the reasons behind China's trans-

* The author would like to thank the very capable assistance of Yunyu Tan.

Figure 1

China Export

Gross export - Gross export as a share of GDP

USD bn

— Gross export as a share of GDP

2500

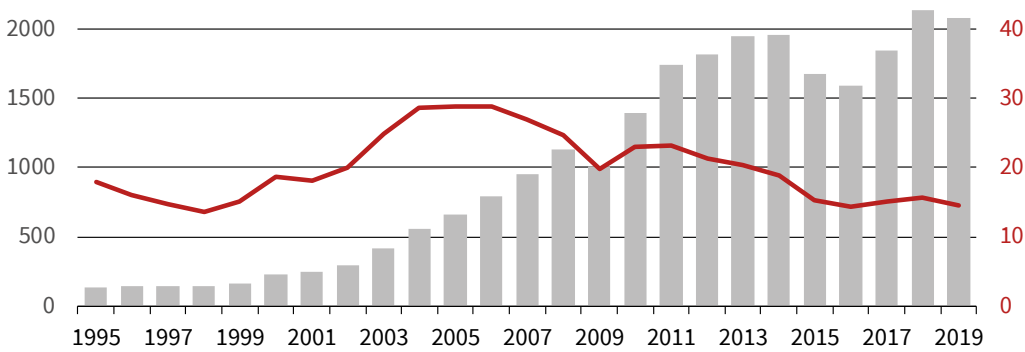

Source: UNCTAD. formation and what it means for the WTO and the ongoing discussion for China's reform.

\section{CHINA'S ACCESSION INTO WTO AND ITS ECO- NOMIC SUCCESS}

China's economic success in the last few decades is clearly linked to its accession to the WTO but not only in terms of market entrance. Tan (2021) contends that China's accession to the WTO brought about major change and tied a rising China more tightly to global economic networks and institutions. The key to success was the reforms that China introduced, which enabled it to fulfill its commitments to the WTO. China's emergence as an economic superpower since 2001 has been meteoric: gross exports expanded fourfoldfrom 243 billion USD in 2001 to over 1 trillion USD in 2009, taking it from the world's the sixth largest exporter of goods to the world's largest exporter (Figure 1). Within five years, the share of export in GDP rose by 10 percent points, from 18 percent in 2001 to nearly 29 percent in 2005. Thanks to the export-led growth model, China's rapid export growth has been accompanied by rapid growth in income. GDP per capita more than doubled from 1,053 USD to 2,099 USD from 2001 to 2006 and multiplied by almost ten times to 10,261 USD in 2019 (Figure 2). Be that as it may, the growth story of China is still unfolding.

It seems important to go back to the history of China's accession as well as the commitments to better understand where we stand today. China's entry into the WTO was clearly not smooth. In fact, China was one of the 23 original signatories of the General Agreement on Tariffs and Trade (GATT), the predecessor of the WTO. But after China's revolution in 1949, the situation between Taiwan and the mainland was all but easy. There are many interpretations of what happened then, but it ultimately boils down to China withdrawing from the GATT system. In 1982, the Chinese government was granted observer status of GATT and in 1986, China formally applied to accede to the GATT in the form of a "resumption of its status as a contracting party." For 15 years after its initial application, China engaged intermittently in bilateral negotiations with Japan, the US, the EU and other WTO members, as well as the multilateral negotiations in the WTO Working Party on Accession. The first developed country to reach a bilateral agreement with China was Japan, which gave new momentum to other bilateral negotiations. The bilateral negotiations between the US and China, which held the key to accession, were stalled by suspensions that were imposed after the Tian'anmen Square incident 
(June 1989) and the accidental bombing of the Chinese Embassy in Belgrade (May 1999), but a US-China agreement was reached in Beijing in November 1999. The EU reached a substantial agreement with China as well in May 2000. Consequently, the bilateral negotiations with the major developed countries were virtually completed. As of February 2001, China had roughly completed negotiations with all 37 of the WTO members requesting the bilateral negotiations, with the exception of Mexico. This was the last country to give up its implicit veto, opening the door for China's accession to the WTO on 11 December 2001.

In short, China's accession to the WTO was preceded by a lengthy process of negotiations that required significant reforms to transform its economy into one which is more market based. The results of bilateral negotiations on market access were extended to all members under the most-favored-nation principle. Regarding market access for goods, China agreed to reduce import tariffs and to eliminate quantitative restrictions on imports by 2005. China also committed to unifying all laws, regulations and standards, applying discriminatory standards to imports by the time of accession to the WTO, and to ensure transparency of the system as well as equal treatment between imports and domestic products. China's concessions on market access for services was more limited but it did agree to a phase-out of restrictions to entry to foreign investors that vary widely across sectors.

It is also important to look into the safeguard, or emergency measures, that the WTO allows (Shaffer and Gao 2018). Such safeguard measures ordinarily take the form of tariff hikes or quantitative restrictions. Subsidies are an exception to the principle of national treatment and the WTO agreement does allow subsidies to be provided only to domestic industries. Government procurement is also an exception to the principle of national treatment. Governments are allowed to preferentially purchase domestic goods when sourcing goods as the final consumer. The WTO agreement sets forth rules on these measures so that they are not abused to create barriers to trade. As a general principle, China was required to adhere to these rules when joining the WTO, but conditions differ according to the specific agreement.

The very important issue of adherence to commitments to subsidies has so far been watered down as China has kept is status of developing economy. Regarding procurement, China decided not to join the plurilateral agreement binding members for international procurement rules and the situation has not changed. In any event, as part of the accession process, China did agree to guarantee non-discrimination against foreign and foreign-capital companies in applying conditions to the procurement of inputs and goods and services. It is also committed to eliminating the discriminatory two-tiered pricing system for foreign companies purchasing transportation, energy and telecommunications services charges. In terms of
Figure 2

Gross Domestic Product

Per capita in USD

12000

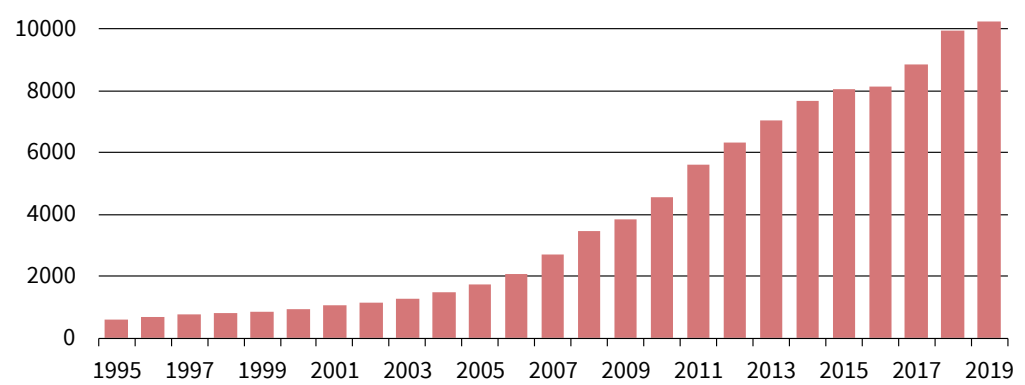

Source: The World Bank.

(c) ifo Institute

protecting intellectual property, China amended legislation to bring it in line with obligations of the TRIPS. Among several actions, China amended its criminal law, adding penalties for intellectual property rights infringement, it has provided a legal framework for protecting intellectual property rights by the customs authorities, the State Administration for Industry and Commerce (SAIC) was given power to prosecute infringements, and a specific section was set up at the Supreme People's Court to handle this. Still infringement is rampant. In the case of technology transfer, legislation in China remained, which was inconsistent with the TRIPS agreement, such as the "Technology Importation Contract Control Ordinance" and concomitant enforcement rules, which impose restrictions on international technology importation contracts (i.e., licensing contracts).

Regarding standards and certification, the WTO, under the GATT non-discrimination principles, contains rules on technical standards and certification so that arbitrary standards and technical requirements at the national level do not constitute technical barriers to trade. China was very far from WTO commitments on this front at the time of accession. Different authorities or institutions were in charge of product inspections depending on whether the product was domestic or imported. Also, the standards by which products were inspected lacked transparency. Various steps have been taken since then, including the creation of China compulsory certification, but problems leading to discrimination toward foreign products remain.

Regarding anti-dumping and countervailing duties, China formulated its own legislation in 1997 and began investigations at the end of that year into newsprint from Canada, Japan, Republic of Korea, and the US but its legislation was not in line with that of the WTO. Regarding the use of anti-dumping and countervailing duties against China by WTO members, it is important to note that the scope and approach change substantially depends on whether China is considered a market economy. The US-China bilateral agreement for accession in November 1999 treats China as 
a "non-market economy" for the first 15 years after accession and allows the use of third-country domestic prices and production costs in the calculation of normal values.

\section{EVOLUTION AFTER CHINA'S ENTRY INTO THE WTO}

The Chinese economy has gone through several reforms and "opening-ups," which have obviously helped fulfil the requirements set in China's WTO accession, but China has clearly fallen short of becoming a market economy. In fact, China does not define itself as such, but rather as a socialist economy with Chinese characteristics. Overall, one could argue that China remains a mixture of a planned and a market economy.

The key question remains as to how compatible this model is with that of other WTO members. A good reflection of the lack of compatibility is the use of WTO safeguarding measures, especially anti-dumping ones, against China. Even though China clearly stands out as a target for anti-dumping initiation, it is not the worst performer. Up to the end of 2018, China has been charged with 258 cases of anti-dumping since its entry into WTO (Figure 3 ), and this number is much smaller than that of the United States (659 cases) and that of the EU (502 cases). In terms of the source coun-

Figure 3

Anti-dumping Initiations through WTO

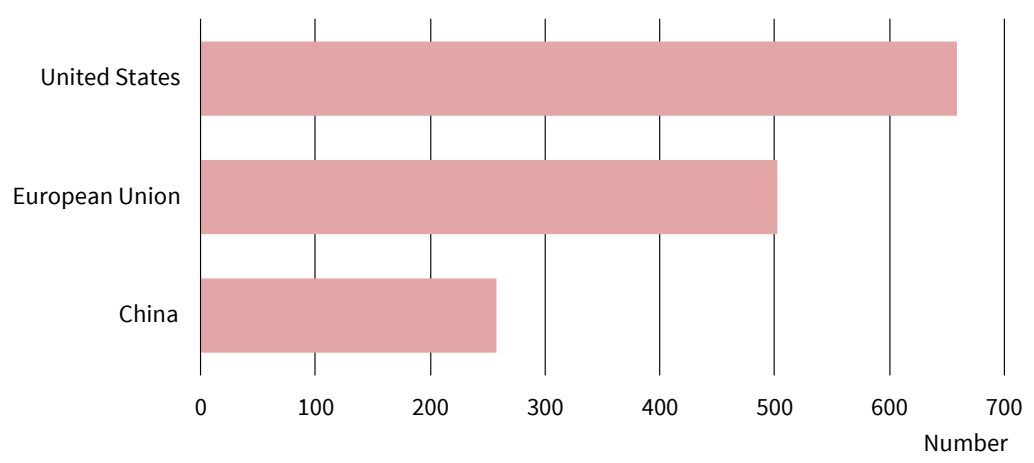

Source: Natixis; WTO.

(c) ifo Institute

Figure 4

Anti-dumping Initiations against China Breakdown by Country
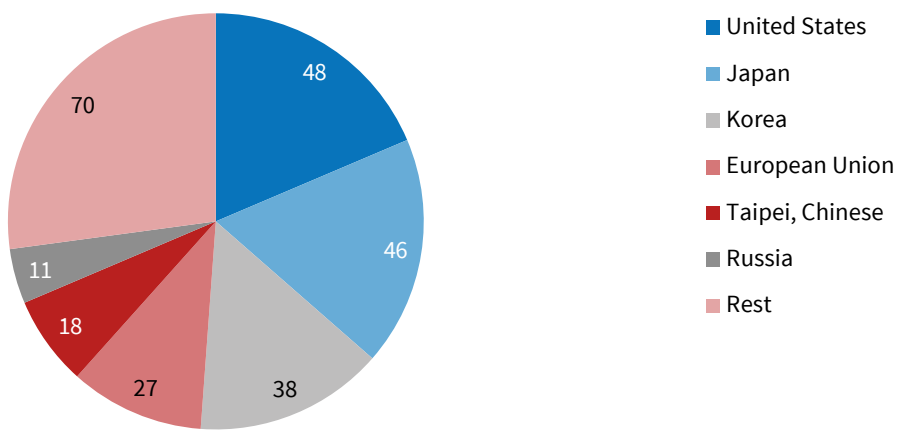

Source: Natixis; WTO. try, the US stands out as having initiated 48 cases of anti-dumping against China, which makes up more than one-fourth of the total anti-dumping initiations against China (Figure 4).

Neighboring economies such as Japan and Korea have also been a major initiator of anti-dumping cases against China. The number of anti-dumping cases against China might, however, been biased downward, especially more recently, due to China's reaction through retaliation. This is inherent in China's economic model and the dominance of state-owned enterprises (SOEs) in many sectors, which receive government support when dealing with pressure from overseas. In fact, the sectoral distribution of anti-dumping cases against China already points to this hypothesis as China's chemical products have been under the greatest amount of attack, with 140 cases of anti-dumping or more than half of the total anti-dumping initiations against China. This sector is indeed dominated by large SOEs (Figure 5).

\section{WHY WE STILL NEED A REFORM}

While China was not the first or even the last non-market economy to enter the WTO (Vietnam followed China, for example), there are a number of reasons why China is a much more important case for the future of the WTO and the need for reform. The most obvious reason is China's sheer size. China today is the second-largest economy in the world, or even the first when measured in terms of purchasing power parity (PPP). In addition, its companies have continued to grow, and now top the rankings of the largest companies in the world. In fact, China now has more Fortune 500 companies than the US (Figure 6), which means that any distortions in an economy of the size of China, which also has such a large number of huge companies, have global implications. Vietnam cannot really compare with China, size or influence-wise. The other important reason why China makes a case for WTO reform is related to the large role the state plays in the Chinese economy.

The role of the state in the Chinese economy has long been debated both in the economic literature and in political circles, and the dispute has by no means been settled. To this end, we show the share of corporate assets still in state hands, particularly among listed companies. In fact, as of the first half of 2020, 58.9 percent of assets were in the hands of SOEs, regardless of whether they were central or local SOEs. This percentage is even higher in the telecom, infrastructure, airlines, energy and utilities sectors (Table 1). While the pervasiveness of state control in the production of goods and services already points to potential distortions in the Chinese economy, pushing it away from market functioning, one could argue that ownership does not necessarily determine how a company may behave. In fact, 
the concept of "competitive neutrality" is designed to measure how close the behavior of a state-dominated entity may be to that of a private company in the production of goods and services. In a recent paper by García-Herrero and Ng (2021), the authors measure sector by sector how far Chinese SOEs are from competitive neutrality in the domestic market. They find that SOEs are generally advantaged compared to their private counterparts except for the real estate sector.

Another important role of the state in the economy is that the Chinese Communist Party (CCP) is intrinsically involved in the functioning of companies in China. In particular, the CCP appoints and controls key company executives through the CCP Organization Department. In addition, both stateowned enterprises and private Chinese companies have internal Party committees that are capable of performing government and Party functions. In recent years, moreover, the Party has taken steps to increase the strength and presence of Party committees within all companies. For example, state-owned enterprises and private Chinese companies are being pressured to amend their articles of association to ensure Party representation on their boards of directors, usually as the Chairman of the Board and to ensure that important company decisions are made in consultation with Party cells. Further reinforcing the Party's influence over enterprises in China is the Social Credit System, which monitors and rates individuals and companies in China, including foreign ones.

More generally, the strategic planning stemming from China's latest Five-Year Plans and beyond makes it very clear that China wants to remain a socialist economy with Chinese characteristics and that the overarching role of the state is not going to wane. Both China's growth size and its economic model have a huge impact on the function of the WTO, making a reform even more necessary, in addition to other reasons.

China is obviously not the only country with a state-led economic model, which means that a reform is bound to affect many other economies. The most serious issue is related to SOEs that dominate many economies, especially in Gulf countries and Vietnam. There are basically no specific obligations regarding SOEs within the WTO agreement. The Agreement on Subsidies and Countervailing Measures (SCM) does not even mention SOEs. The second key issue is technology transfer. The US and others have also voiced concerns about China's use of informal nonstate channels and informal norms not openly articulated by a government official. The issue is only partly addressed within the existing WTO rulebook, which fails to specify what constitutes a "forced" technology transfer. The GATT and other multilateral agreements do not cover investment for goods, nor do they therefore address transfer of technology.
Figure 5

Anti-dumping Initiations against China, Sectoral Distribution

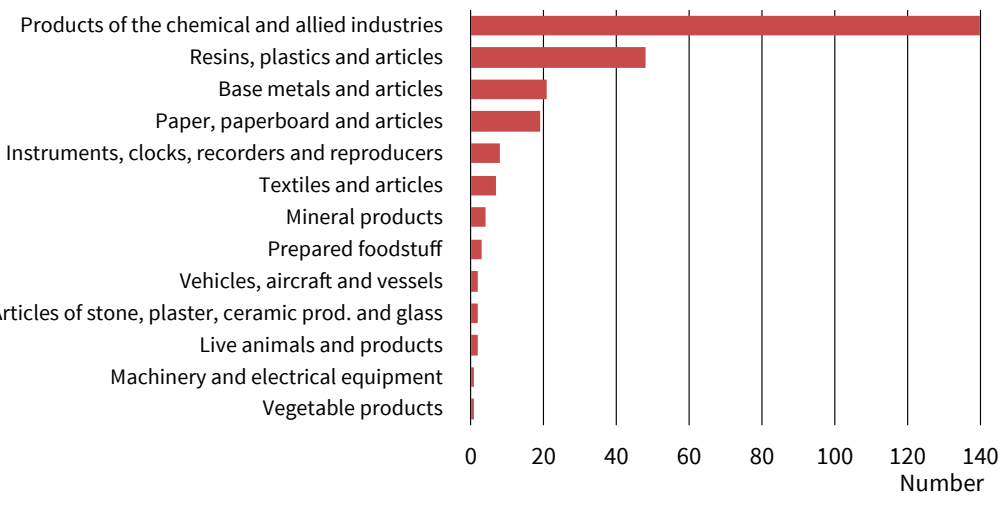

Source: Natixis; WTO. (c) ifo Institute

\section{Figure 6}

Companies in the Fortune 500

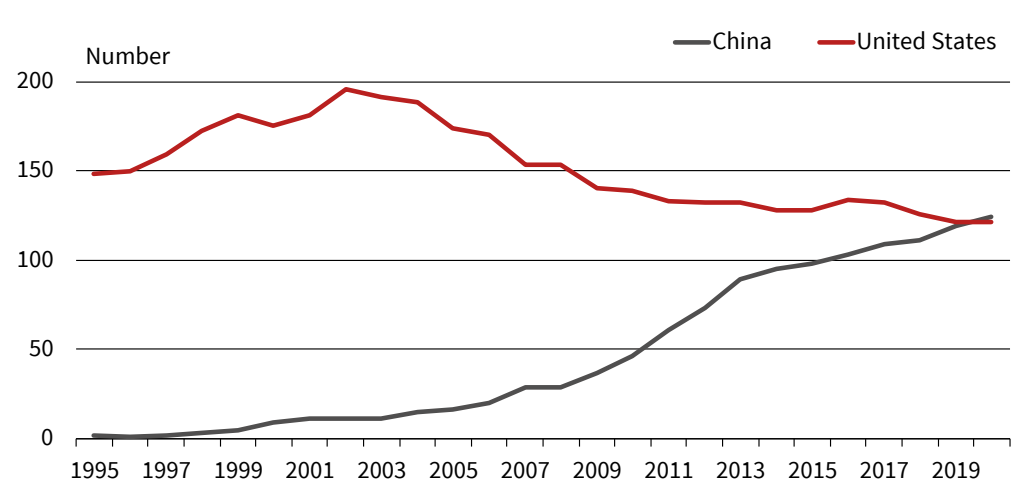

Source: Fortune; Natixis.

(c) ifo Institute

On the other hand, the GATS (General Agreement on Trade in Services) is the only multilateral agreement that covers investment. In addition, the Agreement on Trade-Related Aspects of Intellectual Property Rights (TRIPs Agreement) has something to say about this as well.

The other important issue is the developingcountry status. The WTO treaties provide certain exceptions and more permissible rules for developing countries, which, under the special and differential treatment (S\&D), are entitled to longer time periods for implementing agreed commitments, measures to increase trading opportunities and twice the number of agricultural subsidies available to developed countries. However, there are no set rules for what constitutes a "developing country"-meaning that this is an issue of self-declaration. Most of the WTO's members claim to be developing, including China. Hence, the system allows China to enjoy preferential rules in some areas, despite the fact that it is a larger trading power than many advanced economies and that it has the largest number of Fortune 500 companies, and that it is the first-/second-largest economy in the world. It seems clear that WTO rules were not crafted with the unique structure of China's political economy in mind and that reform is clearly needed. 
Table 1

Ownership by Sector Measured by Asset Size (\%) for 3,000 Largest Listed Corporates in China, First Half of 2020

\begin{tabular}{l|ccc}
\hline Sector & Central SOE & Local SOE & $\begin{array}{c}\text { Private-owned } \\
\text { enterprises (POE) }\end{array}$ \\
\hline Telecom & 98.6 & 0.0 & 1.4 \\
Infrastructure & 79.1 & 14.6 & 6.3 \\
Airlines & 78.1 & 15.4 & 6.5 \\
Energy & 81.3 & 11.9 & 6.8 \\
Utilities & 65.9 & 27.0 & 7.0 \\
Industrial & 41.9 & 31.6 & 26.5 \\
Automobiles & 20.3 & 43.0 & 36.7 \\
Materials & 23.3 & 37.2 & 39.5 \\
Total & 39.1 & 19.8 & 41.1 \\
Health care & 24.5 & 15.5 & 60.0 \\
ICT & 22.7 & 13.5 & 63.7 \\
Real estate & 21.1 & 12.4 & 66.5 \\
Consumer & 4.1 & 23.7 & 72.1 \\
Semiconductors & 7.3 & 16.3 & 76.3 \\
Renewables & 13.4 & 6.8 & 79.8 \\
\hline Source:Natis. & & &
\end{tabular}

Source: Natixis. step in that direction but with many important issues left for a second phase and/or a reform of the multilateral system. This includes critical issues such as subsidies, excess capacity, state-owned enterprises, state-sponsored cyber-enabled theft of intellectual property, standards, cybersecurity, data localization requirements, restrictions on cross-border data transfers, competition policy and regulatory transparency as well as intellectual property, technology transfer and services market access.

The first thing to note is that, based on the 2017 USTR Report to Congress on China's WTO Compliance, the Trump administration clearly did not believe that reforming the WTO would solve the problems involving China's state-led economic model as China became part of the global economy. It is still too early to know whether this view will be held by the current Biden administration, but there are some preliminary signs that this might be the case. In other words, WTO reform might be on Biden's agenda but not as his main tool for dealing with it.

This is indeed the position of Mark Wu, recently appointed by the University of Pennsylvania to work on a project involving the future of US-China relations, who states in his recent paper on US-China, how he believes the trade challenge should be handled (Wu 2020). Wu underscores the difficulties of a WTO-centric strategy for any joint alliance-based approach for tackling the China trade challenge in the short term (more specifically, he refers to the 2021-24 period). Wu believes that the reasons for these difficulties are that the urgency to formulate a response contrasts with the very slow speed at which such large multilateral institutions operate. Still, he advocates US involvement in the WTO and its reforms, and that there should be a clear focus on resolving differences with US allies as to the direction reform should take, and that more timely ways of dealing with China need to be developed as far as trade and investment are concerned. This multi-pronged approach for dealing with China seems like the most likely action that the Biden administration will take.

Regarding the WTO, one important aspect of the reform expected by the US administration regarding China relates to increasing the speed for introducing new rules. One way to speed up this reform is to foster the consensus process that WTO ministers use and to implement Annex IV Plurilateral Agreements, to which only a select group of countries currently agree, but which is an agreement that other countries are also free to agree to. There are a number of problems with this, such as potential free riding, as well as a minimum threshold of membership that must be covered.

It is also important that the most obvious shortcomings of the current WTO rules are covered, such as subsidies, e-commerce, and services. Two problems emerge in this context. First, only industry-related 
subsidies are partially covered under the WTO. Service-related subsidies are excluded. Second, it is not clear whether other bilateral arrangements can be used as a formula for WTO reform. The recent investment deal reached between the EU and China offers a new formula for service subsidies, at least in terms of additional transparency but does not introduce any changes to industrial subsidies, which means that there is no new guidance as to how to address this issue within WTO reform. Regarding e-commerce, formal negotiations have started at the WTO on a new plurilateral rule, but US and China positions are really far apart.

\section{The EU's Proposal}

The European Union has been one of the key supporters of multilateralism and the WTO, but has urged reform during the past few years, because the US government (and the Trump administration in particular) turned its back on the WTO. In 2018, the EU published a concept paper with a detailed proposal for WTO reform, focusing on a range of issues, such as overcoming the deadlock of the dispute settlement system, among others (European Commission 2018). More recently, on February 18 this year, the EU published a review of its trade policy, which also included WTO reform of as one of its key issues (European Commission 2021). While the approach to WTO reform in the EU's 2018 document does address some of the key issues related to China, its 2021 document states digitalization and climate change as the EU's key views. Multilateral means (WTO) and bilateral trade deals seem to come closer together in terms of priorities, and assertiveness appears as an important new concept. Finally, in its latest trade policy review, the EU is increasingly pushing the idea of using multi-country deals when consensus cannot be reached at the WTO level.

A number of issues should be highlighted regarding the EU proposals for WTO reform that directly relate to China. First, market distortions from non-market economies should be one of the key objectives addressed, which is very similar to the US position. The EU, though, seems to link market distortions to state involvement in the production of goods and services (namely SOEs), whereas the US position is more nuanced, based on the increasingly pervasive influence of the CCP in private companies. With regard to subsidies, the EU and the US recognize that the Agreement on Subsidies and Countervailing Measures (SCM Agreement) is not as effective as would be necessary. Therefore, one of the key aspects of the EU's proposal is to improve transparency regarding subsidies, since the lack of information makes it close to impossible to pursue cases at the WTO. Regarding SOEs, there is the additional problem that they can be classified as "public body" and thus escape the responsibilities imposed by the SCM
Agreement. For the EU, WTO reform would need to clarify the commercial nature of SOEs so that they are fully covered by existing WTO commitments on subsidies and other non-market practices. It should be noted that the EU-China investment deal does include a clause clarifying the nature of SOEs, which could serve as a basis for reforming the WTO on this specific topic.

The EU proposal does recognize that, even with better transparency on subsidies and better coverage of SOEs in existing mechanisms such as SCM, other-market distorting measures from non-market economies need to be addressed with a WTO reform. To start with, some types of subsidies are still permissible within SCM, which means that the list of prohibited subsidies would clearly need to be expanded. These include unlimited guarantees and subsidies given to an insolvent or ailing enterprise with no credible restructuring plan or dual pricing.

Beyond subsidies and SOEs, the EU proposal also includes new rules to address barriers to services and investment, including forced technology transfer, market access barriers and discriminatory treatment of foreign investors. Starting with forced technology transfer, the scope of application of existing provisions in the WTO rule is limited and therefore insufficient for addressing some of the most important sources of problems, such as requirements prohibiting or limiting foreign ownership (e.g., joint venture requirements or foreign equity limitations). The recently signed EU-China investment deal improves on the existing rule book on forced technology transfer, which follows the example of the US-China Phase 1 deal. This improvement could be a first step toward reforming the WTO on this specific topic but it is clearly not sufficient. In fact, the EU position paper calls for new rules to improve overall market access conditions for FDI.

The final point that the EU position paper focuses on is the developing versus developed status when it comes to WTO policies (European Commission 2021). In fact, the idea that such difference should be made stems from the assumption that developing countries benefit less from trade. China is probably the best example of the opposite and there are many others, such as Vietnam. The EU holds the view that the lack of nuance and its consequences with regard to the special and differential treatment question has been a major source of tensions in the WTO and an obstacle to the progress of negotiations. The demand for blanket flexibilities for two-thirds of the WTO membership dilutes the call from a much more targeted group of countries that do have development assistance needs. The EU proposal does not offer a specific solution to this problem, but the direction is clear: reduce the number of countries considered developing and, implicitly, move away from each WTO member deciding on their own status independently. 


\section{China's Proposal}

Against the backdrop of rising unilateralism and protectionism, China is also in support of making necessary reform to the WTO. To this end, China has submitted two formal documents on the topic of WTO reform, these being the Position Paper on WTO Reform of November 2018 and the Proposal of China on WTO Reform of May 2019 (WTO 2019). In general, China's primary focus is how to bring the Appellate Body to work again but also, fisheries subsidies, e-commerce and investment facilitation. As for the more controversial topics such as trade distortions and subsidies, China still defends its interest and stresses the uniqueness of its economic structure. Key complains such as forced technology transfer are not mentioned in these proposals even though China did respond by introducing a new investment law in 2019 which states a prohibition on forced technology transfer.

Regarding the behavior of SOEs, China maintained a tough position and reasoned that SOES are equal players in the market whose only difference is ownership. In that regard, China would like to avoid discrimination against SOEs in foreign investment security reviews by WTO members. In other words, China' s position is that it would accept discriminatory disciplines on SOEs in the name of WTO reform and that foreign investment security reviews should be conducted in an impartial manner.

As for subsidies, China does admit the potential misuse and abusive application of trade remedies, in particular discriminatory practices based on country-of-origin and types of enterprises. However, it attributes the problem to the ambiguities in existing multilateral trade remedy rules. As such, it proposes to further clarify and improve relevant WTO rules on subsidies, countervailing measures and anti-dumping measures. That said, it still stresses the need to give consideration to the special situations of developing members and gives no signal that it was to move away from such status.

Beyond the US, the EU and China positions on this issue, the economic literature also proposes a few ways to reform WTO as concerns China, especially around the key complaints such as the unfair trade advantages of SOEs and the use of forced technology transfer on foreign companies. A very important case in point is the recent book on China and the WTO by Mavroidis and Sapir (2021). The authors try to offer a middle ground and conclude that, for the WTO to function smoothly and accommodate China's unique geopolitical position, the WTO needs to translate some of its implicit principles into explicit treaty language. More specifically, the authors propose that the WTO translate its implicit legal understanding into explicit treaty language. China will then have the choice regarding whether it wants to comply, which they believe will be the way to accommodate
China. Another important recommendation from the authors is to limit the role of the state in the economy to unleash the potential for liberalization.

\section{CONCLUSIONS}

China's accession to the WTO has been a landmark event both for China and the rest of the world. In fact, it has been instrumental in embarking an economy of the size and population of China in competing in the global economy and the result has been a great success. To achieve that goal, China has no doubt reformed and opened up its economy but not to the extent of becoming a full market economy. That duality-striving to operate as a market economy in some areas while keeping the key characteristics of a state-led planned economy-makes it very difficult for China to comply with the principles of what the WTO, as an institution, was designed for. Therefore, a reform is not only necessary but also long overdue. The key problem, though, is that China-and probably other emerging economies with a largely state-led economy or with big industrial policy plans-may feel more comfortable with the kind of WTO rules we have today than with the proposals for reform coming from the US, the EU or Western academics in general. At the other end of the spectrum, the US administration (certainly under Trump but possibly also under Biden, given his team choice) does not seem ready to wait for a multilateral solution in terms of China's trade and investment issues, and certainly not for a reform of the WTO. This means that an increasing number of autonomous measures for dealing with China's economic threat are to be expected. A very good example of it is the executive order that the Biden administration has announced to protect value chains from Chinese components in certain key sectors. Beyond autonomous measures, the Biden administration is prepared to work with like-minded countries on WTO reform, but acknowledges that reform will not come in time to address China-related problems. This is why the US administration seems ready to choose a faster route to improve its trade and investment relations with China. One potential outcome will be for the US to push a bilateral negotiation beyond the Phase 1 deal covering the most contentious issues, such as subsidies, SOEs and forced technology transfer. At the same time, a US-EU-led WTO reform (with other like-minded countries) will probably focus on all the above, with some help from the EU-China investment deal that will also clarify when countries can claim developing-country status. It goes without saying that the EU-China investment deal only offers a partial solution to some of the issues, such as transparency for subsidies on services, as well as transparency on SOEs activities, especially those involving their commercial goals. Many other issues will still need to be resolved. Within that context and based on China's own position on WTO reform, the lack of consensus 
is blatantly clear. This is particularly true for treating SOEs.

Both the need for urgency in dealing with market distortions stemming from China's economic model and China's increasing size and influence on the rest of the world might not necessarily be channeled toward the WTO. The reasons for this are several. First and foremost, China seems unwilling to give up its status as a developing country and the benefits that come with it, and WTO procedures are simply too slow for such a change to occur at an acceptable speed. This means that either bilateral solutions (such as the EU-China investment deal) or a potential follow-up of the Phase 1 deal may be used as a bridge to WTO reform. In parallel and especially on the front of dispute settlement, multi-country arrangements might be the preferred option while a slow, but hopefully feasible, WTO reform is achieved.

\section{REFERENCES}

European Commission (2018), WTO Modernization: Introduction to Future EU Proposals, Concept Paper, https://trade.ec.europa.eu/doclib/ docs/2018/september/tradoc_157331.pdf.

European Commission (2021), Trade Policy Review - An Open, Sustainable and Assertive Trade Policy, Communication from the Commission to the European Parliament, the Council, the European Economic and Social Committee and the Committee of the Regions, COM(2021) 66 final, 18 February, https://ec.europa.eu/transparency/regdoc/rep/1/2021/EN/ COM-2021-66-F1-EN-MAIN-PART-1.PDF.
García-Herrero, A. and G. Ng (2020), Natixis China Corporate Monitor 2020: Weaker Financial Health But Finally Overtaking Hard-hit Global Peers, Natixis Research, Paris.

Mavroidis, P. C. and A. Sapir (2019), "China and the World Trade Organisation: Towards a Better Fit", Bruegel Working Paper 6.

Mavroidis, P. C. and A. Sapir (2021), China and the WTO: Why Multilateralism Still Matters, Princeton University Press, Princeton.

Shaffer, G. and H. Gao (2018), "China's Rise: How It Took on the U.S. at the WTO", University of Illinois Law Review 2018(1), 115-184.

Tan, Y. (2021), "How the WTO Changed China: The Mixed Legacy of Economic Engagement", Foreign Affairs March/April, https://www.foreignaffairs.com/articles/china/2021-02-16/how-wto-changed-china.

United States Trade Representative (USTR, 2018), 2017 USTR Report to Congress on China's WTO Compliance, https://ustr.gov/sites/default/files/ files/Press/Reports/China percent202017 percent20WTO percent20Report.pdf.

United States Trade Representative (USTR, 2020), Trade Policy Agenda and 2019 Annual Report of the President of the United States on the Trade Agreements Program, https://www.wita.org/wp-content/uploads/2020/02/2020_Trade_Policy_Agenda_and_2019_Annual_Report. pdf.

World Trade Organization (WTO, 2019), China's Proposal on WTO Reform: Communication from China, http://images.mofcom.gov.cn/ sms/201905/20190514094326217.pdf.

Wu, M. (2020), "Managing the China Trade Challenge: Confronting the Limits of the WTO", Working Paper for the Penn Project on the Future of U.S.-China Relations, https://cpb-us-w2.wpmucdn.com/web.sas.upenn. edu/dist/b/732/files/2020/10/Mark-Wu_Limits-of-WTO_Final.pdf. 